\title{
POSSIBILITIES FOR DEVELOPMENT OF RECREATIONAL TOURISM IN SOKOBANJA
}

\author{
Miloš Marjanovićl \\ Received: June 32017 | Accepted: July 21, 2017
}

\begin{abstract}
The modern way of life and work has a big impact on the use of leisure time and rest. Considering that the contemporary work is less dynamic and excludes physical activity, in each person creates the need for appropriate activities, which will catch up basic human needs in free time, embodied in the entertainment, movement, recreation and game, in order of better and higher quality of life. Active holidays, as a global trend, with big steps takes precedence in the use of leisure time with the modern human. Serbia is certainly very interesting as a destination for the development of this type of tourism, due to its natural and geographical diversity. Sokobanja is one of the most important and most visited spas in Serbia, and it has great potential for active holidays. Climate characteristics, directly mountainous environment, untouched nature, thermal and mineral springs and streams form the basis for the development of modern ways of tourism - active holiday. In this paper, I will analyze the potentials for the development of recreational tourism in the municipality of Sokobanja, current state of development, opportunities for development, material base and tourist traffic, as well as factors that limit the dynamic development of tourism and recreation.
\end{abstract}

Keywords: Sokobanja, recreational tourism, active holidays

\section{INTRODUCTION}

The development of industrialization in the world in the 19th and 20th centuries led to the fact that man was increasingly alienated from nature, he had less time for himself, and he was increasingly consumed physically and mentally. Such alienation negatively affects his working but also psycho-physical morale. Hence, there were various protests by workers, who wanted to increase their rights. There was a need for recreation. A large number of countries were introducing various forms of recreation for their workers in order to achieve their psycho-physical recovery and rest. In the former socialist countries, which include our country, Serbia, various social and trade union organizations were the initiators of a massive recreational movement (Čomić et al., 2008). In Serbia,

\footnotetext{
Cvijićeva 9/19, 18000 Niš, contact: milos.marjanovic@mail.com
} 
after the Second World War, spa and mountain centers were activated massively, and the most famous are Vrnjacka Banja, Sokobanja, Kopaonik, Zlatibor, and an increasing number of people took part in this form of touristic movements.

Active vacation is a specific type of tourism that involves a large number of leisure and recreation activities that are directly related to healthy life, fun and entertainment, in order to restore and recover human psycho-physical strength. Modern way of life and work, as well as life in urban surroundings, affects contemporary society, so, more and more people accept an active way of resting (Blagajac, 1992). A man uses various sportsrecreational activities whose contents represent natural forms of movement, in accordance with their health condition, abilities, needs and interests. Given that some basic human needs such as movement, fun and play can be satisfied with sports and recreation, active holidays represent a new trend in the development of tourism, which differs from the traditional content of the holiday. Active vacation includes numerous activities in an attractive natural environment, which are different from everyday work. It is essentially a way of resting with various activities in order to maintain and improve the psycho-physical state of the organism in an attractive natural environment (Bartoluci, Andrijašević, 2006).

Sokobanja possesses natural potentials that are extraordinary for active rest. A large number of activities that contribute to the establishment or maintenance of biological and psychological balance, can be practiced in the attractive surroundings of the Sokobanja basin, some of which include hiking, running, swimming, cycling or rollerblading, sailing and rafting.

Sokobanja basin is located in the central part of eastern Serbia. It covers an area of $525.5 \mathrm{~km}^{2}$. In the morphological view of the Sokobanja basin, it is part of the mountainvalley macro-region, and the part of eastern Serbia (Pavlović, 1995). From all sides it is surrounded by mountains of middle height: Rtanj $(1,567 \mathrm{~m})$ in the north, in the east are Slemen and Krstatac, in the southeast is Devica, in the south is Ozren, and in the southwest is Bukovik. It is $60 \mathrm{~km}$ away from Niš and $30 \mathrm{~km}$ from the highway E-75, the main tourist route in our country. It is $240 \mathrm{~km}$ away from Belgrade.

The possibilities of development of recreational tourism in Sokobanja are based on the richness of natural tourist values such as climatic characteristics, vegetation, thermo-mineral springs and favorable tourist-geographical position. Complementarity of development of spa tourism with mountain tourism is of fundamental importance for further development of tourism in Sokobanja. The possibilities of developing recreational tourism in Sokobanja are considerably higher than the current situation, material base, the content and the length of the tourist stay. The proximity of the city of Nis, as the main emitting area and proximity to the airport "Car Konstantin", increases the tourist value of Sokobanja. 


\section{NATURAL RESOURCES IN THE FUNCTION OF RECREATIONAL TOURISM IN SOKOBANJA}

The nature of the Sokobanja region is a good base for the development of tourism. In spite of that, a good part of the tourist potentials is not sufficiently and adequately presented to the tourist market. Therefore, due to the poor economic conditions (both at the level of Serbia, and especially in the area of eastern Serbia), the tourist potentials of the Sokobanja basin have not been sufficiently valorized, which is a limiting factor for further development. The stay of tourists in this area should be based on an optimal combination of attractive natural attributes that will directly enable active vacation (Radivojević, 2010).

Sokobanja has numerous and varied natural tourist values that represent the basis of tourism development in this region. Climatic characteristics, direct mountain environment, thermo-mineral springs and watercourses provide excellent conditions for psycho-physical rest and recovery of human.

The combination of climate factors in the territory of Sokobanja enables the development of healthcare tourism and recreational tourism. The favorable climatic features that characterize the Sokobanja basin are classified into the ranks of the spa-climatic sites, that is why Sokobanja carries the epithet of the air spa. Analyzing the condition of certain climatic elements, the climate of Sokobanja is defined as climate of pleasant feeling zone. This is confirmed by the fact that the mean annual air temperature is $10,29^{\circ} \mathrm{C}$. The coldest month is January with an average temperature of $-1.25^{\circ} \mathrm{C}$, and the warmest July is $21.4^{\circ} \mathrm{C}$ (Maćejka, 2003). The average number of days in a year with an air temperature above 18 ${ }^{\circ} \mathrm{C}$, which is suitable for tourist movements and is considered as a tourist season, is 92 days. The average temperature in the winter part of the year is $-0.6^{\circ} \mathrm{C}$, in the spring $10.6{ }^{\circ} \mathrm{C}$, in the summer is $20.2{ }^{\circ} \mathrm{C}$ and in the autumn $12.0^{\circ} \mathrm{C}$. The annual amount of rainfall is 599 $\mathrm{mm}$, and based on this, Sokobanja is ranked in the spas with a minimum amount of atmospheric precipitation, which does not affect so much on tourism movements (Maćejka, 2003). Relative air humidity is the highest in winter months with a maximum in december of $83 \%$, and the lowest in august is $68 \%$. The annual insolation value is $1,861.5$ hours, or an average of 5.09 hours per day (Radivojević, 2008). The combination of climatic elements of this space sedatevly acts on the organism of human. Climate of Sokobanja can occur as direct and indirect tourism value. If it occurs as an element of climatotherapy, which is, in the function of recreation, it is considered as a direct tourist value. As an indirect tourist value, the climate of Sokobanja is reflected in its activity on the flora and fauna, hydrogeological objects and relief, emphasizing their tourist attraction.

The possibilities for the development of different types of recreational tourism are closely related to the morphological features of this region. In the touristic view, the most interesting mountains are Rtanj and Ozren. Rtanj, a strict nature reserve, is the highest mountain of the Sokobanja basin with the peak Šiljak $(1,565 \mathrm{~m})$. This mountain is characterized by exceptional landscape and pleasant mountain surroundings. Rtanj, with its attractive potential, opens the possibility of developing recreational tourism. Well-marked trails leading from the bottom to the top allow for a longer-term climb in the preserved natural environment. There are traditional trekking actions such as Christmas or Night Rise, but there are many other trekking actions that mountaineers 
and other lovers of this mountain perform, independently, or in groups. It is interesting that the approach to Rtanj is practically possible from all sides, and depending on the current interests and possibilities of individuals, the desired path is chosen. Numerous points of view on Ozren and Devica make these mountains interesting for tourist movements, especially for trips and walks. The attractive potential of Ozren is also contributed by the stimulating sub-mountain climate, on the basis of which, according to the functional classification of the mountains, Ozren is also included in the group of recovery mountain resorts (Stankovic, 2000). A large number of arranged paths lead from the foot of these mountains to the peaks, and one of the most interesting peaks for mountaineers are the Oštra čuka, Čapljinac on Devica mountine. Organized climb to the top of the Oštra Čuka $(1,074 \mathrm{~m})$, the Mountaineering Association of Serbia included this route in the calendar of its regular activities, which is held on September 24th each year.

As an exceptional convenience for the development of recreational tourism in the municipality of Sokobanja, are various biogeographical tourist values. The ambient value, recreational and landscape values of this area are increased by the rich mountain vegetation that covers the entire Sokobanja basin. Large areas of deciduous and coniferous forests, meadows and pastures, arranged parks and rest areas are good for long and light walks by marked paths through unspoiled nature, or riding a bicycle along the mountainous terrain. Arranged parks in Sokobanja and in the surroundings contribute greatly to the psycho-physical recovery of tourists. Some of the parks are the Central city park, park "Banjica", park on Vrelo (Borici), park "Cuka 1" and "Cuka 2". Picnics areas located along Sokobanja basin are very attractive for tourists, which is possible to reach on foot. These are Lepteria, Ocno, Kalinovica, the spring of the Moravica River. Special biogeographical values are medicinal herbs. Sokobanja region has been known for a long time by the medicinal herbs: rtanj tea, kantarion, thyme (Marić, Radović, 1997). More than 200 different types of medicinal herbs were found on the territory of the municipality of Sokobanja. Picking of medicinal herbs and collecting of forest fruits are activities in which tourists can actively participate during their stay.

Thermo-mineral springs of the Sokobanja basin are primary tourist resource, which basically determines the health function of the spa. Based on the hydro-analysis and the chemical analyzes, they are classified into radioactive acratoterms with the character of alkaline waters. All waters are characterized by increased radioactivity, which gives them a special balneological significance. In the area of the basin, thermal water is emptied into six localities, the spring Park, the thermomineral spring Preobrazenje, the spring of Banjica I and Banjica II, the spring of Moravica and the spring of Lepteria (Jovanović, Radivojević, 2006). Thermo-mineral potential of Sokobanja has not been adequately exploited. The development of the spa should be focused on the opening of wellness \& spa centers, as one of the leading trends in spa development in the world. Thermo-mineral potential should be partly focused on filling existing pools and constructing new pools with thermomineral water, steam baths, and the other part should be used for heating them, and the activation of existing infrastructure should be a priority in further development (Košić et al. , 2011). The artificial lake Bovan, and the Moravica river are hydrological facilities that enable the development of recreational tourism in this area. Due to their purity, rivers of the Sokobanja basin (Moravica, Seselacka river, Žlezovac), are suitable for differ- 
ent types of recreational tourism, especially for the development of sport fishing. Moravica is particularly prominent in this area, where there are favorable conditions for the development of bathing tourism (Aleksić, 2005). Artificial lake Bovan, formed by the rebuilding of the Moravica River to supply with water the Municipality of Aleksinac, is a potential touristic motive. The arranged beaches, water sports, sailing, and sport fishing are just some of the activities that tourists can enjoy during their stay.

Beside recreational, some formations also have attractive aesthetic and curiosity attributes such as waterfalls, caves and ice pothole. Waterfall Ripaljka is located on the river Gradašnica. It is $17 \mathrm{~m}$ high and is an accumulating type of waterfalls. It is the first monument of nature in Yugoslavia protected by the law in 1948 (http://www.sokobanja. travel/vodic/izletista/ripaljka). The Sesalačka cave is located near the village of Sesalac, fifteen kilometers east of Sokobanja. It is not touristic arranged, but it is illuminated in the length of $200 \mathrm{~m}$, and it is nice to look on cave jewelry in abundance. The ice pithole at the foot of the Rtanj mountain has a depth of $30 \mathrm{~m}$ and a constant temperature of $-2{ }^{\circ} \mathrm{C}$.

\section{ACCOMMODATION CAPACITIES FOR RECREATIONAL TOURISM IN SOKOBANJA}

In the middle of the 19th century the development of Sokobanja started with the construction of the first accommodations - commercial villas, private rooms, and consequently the development of its accommodation receptive.The first villa, a commercial type, was built for the accommodation of spa guests in 1932. It was a villa "Macedonia", a year later, two more villas were built, but more western than the villa Macedonia. It was the villa "Nada" and "Bota". During the following 1933, three more villas were built: "Milanovo", villa "Serbia" and villa "Ozren". The last built villas in the period before the Second World War were: villa "My Holiday", "Mišić" and villa "Stojanović" (Aleksić, 2005). The greatest progress in development, Sokobanja is experiencing in the period 1975-1987, when it grew into one of the largest and most important spa and tourist centers in former Yugoslavia (Marić, Radović, 1997).

Today, Sokobanja does not have sufficient capacity for accommodation of guests in hotel facilities. All Sokobanja hotels were built in the mid-70s of the 20th century. For many years, hotels have been in the process of ownership transformation, which greatly complicates and stretches excessive investments for the adaptation and maintenance of facilities. There are no high category hotels in Sokobanja, and for the serious development of any type of tourism, the basic tourist facilities should satisfy the needs of a modern tourist. Such capacities are necessary, especially considering the interest of Sokobanja to enter the international market and to become one of the leading congress and health centers of Serbia (Master plan of tourist destination Sokobanja, 2007). Hotel "Sunce" is in the process of ownership transformation and is currently under reconstruction. Adaptation of this hotel will significantly affect the quantity and quality of hotel offer of Sokobanja. In recent years, the Zdravljak hotel has been open to visitors only during certain periods of the year, and during important holidays, thus significantly reducing the offer of hotel accommodation throughout the year. 
Table 1. Number of beds in hotels and medical facilities in Sokobanja

\begin{tabular}{|l|c|c|}
\hline Name of the facility & Category & Number of beds \\
\hline Hotel "Zdravljak" & $3^{*}$ & 512 \\
\hline Hotel Moravica & $3^{*}$ & 210 \\
\hline Hotel Turist & $3^{*}$ & 105 \\
\hline Hotel Sunce & $2^{*}$ & 184 \\
\hline Wellnes \& Spa Center Sokoterme & $3^{*}$ & 35 \\
\hline In total & & 1046 \\
\hline
\end{tabular}

Source: Organization for tourism, culture and sport, Municipality of Sokobanja

The special category of accommodation capacities consists of health facilities, Special Hospital "Banjica" with 270 beds, Special Hospital "Sokobanja" with 530 beds, and special hospital "Ozren" which does not have a commercial part for tourists.

Table 2. Number and structure of accomodation capacities in private households in Sokobanja

\begin{tabular}{|l|l|c|}
\hline Total number of categorized rooms in Sokobanja & \multicolumn{2}{|c|}{2.222 rooms } \\
\hline \multirow{4}{*}{$\begin{array}{l}\text { Total number of categorized beds in domestic } \\
\text { work in Sokobanja }\end{array}$} & First category & 1.517 beds \\
\cline { 2 - 3 } & Second category & 1.897 beds \\
\cline { 2 - 3 } & Third category & 1.189 beds \\
\cline { 2 - 3 } & Fourth category & 234 beds \\
\hline
\end{tabular}

Source: Organization for tourism, culture and sport, Municipality of Sokobanja

Accommodation capacities in private ownership are in the initial phase, without any systemic control and planned development, which affects their categorization (Radivojević et al., 2010). It is believed that there are still about 10,000 beds in the accommodation that is not registered and not categorized. This number is constantly increasing, as many new households are included in the offer. The reduced occupancy of these capacities is influenced by the level of quality of accommodation and services that are offered and which do not meet the standard of modern tourists.

\section{ANALYSIS OF TOURIST TRAFFIC}

The best indicator of the development of tourism in some place is tourist traffic. The organized development of tourism in Sokobanja dates back to 1837, when the first guest came to Sokobanja, so, full 180 years. Sokobanja has a tourist and health function, and Sokobanja is ranked among the centers with the longest tradition in tourism development. Sokobanja is among the most visited spas in Serbia and occupies the second place with $14 \%$ of the total tourist traffic, just behind Vrnjacka Banja, which realizes 26\% of the total realized tourist traffic (Stankovic, 2010). 
Table 3. Number of guests, nights, length of stay in Sokobanja 1996-2016

\begin{tabular}{|c|c|c|c|c|c|c|c|c|}
\hline \multirow{2}{*}{ Year } & \multicolumn{3}{|c}{ Number of guests } & \multicolumn{2}{c|}{ Number of overnights } & \multicolumn{2}{c|}{$\begin{array}{c}\text { Average length of } \\
\text { stay }\end{array}$} \\
\cline { 2 - 9 } & Domestic & Foreign & In total & Domestic & Foreign & In total & Domestic & Foreign \\
\hline 1996 & 40836 & 237 & 41073 & 238404 & 365 & 238769 & 5,8 & 1,2 \\
\hline 1997 & 46872 & 452 & 47324 & 254751 & 1211 & 255962 & 5,4 & 1,8 \\
\hline 1998 & 64955 & 586 & 65541 & 528099 & 1614 & 529713 & 8,1 & 2,3 \\
\hline 1999 & 51051 & 482 & 51533 & 374124 & 1522 & 375646 & 7,3 & 1,3 \\
\hline 2000 & 65434 & 840 & 66274 & 568575 & 3536 & 572111 & 8,7 & 4,2 \\
\hline 2001 & 67226 & 894 & 68120 & 439529 & 3650 & 443579 & 6,5 & 4,4 \\
\hline 2002 & 66141 & 1036 & 67177 & 418422 & 2213 & 420635 & 6,3 & 2,1 \\
\hline 2003 & 60297 & 1463 & 61760 & 396848 & 5852 & 402700 & 6,6 & 4 \\
\hline 2004 & 63049 & 1633 & 64682 & 408538 & 6042 & 414580 & 6,5 & 3,7 \\
\hline 2005 & - & - & 65870 & - & - & 413403 & & 6,27 \\
\hline 2006 & - & - & 67690 & - & - & 412393 & & 6,09 \\
\hline 2007 & 60235 & 1046 & 61281 & 365480 & 5269 & 370749 & 6,07 & 5,03 \\
\hline 2008 & 63128 & 1152 & 64280 & 376850 & 4816 & 381666 & 5,97 & 4,18 \\
\hline 2009 & 55686 & 1263 & 56949 & 330901 & 4959 & 335860 & 5,94 & 3,93 \\
\hline 2010 & 49056 & 1027 & 50083 & 299325 & 3152 & 302477 & 6,1 & 3,07 \\
\hline 2011 & 54984 & 959 & 55943 & 335458 & 3882 & 339340 & 6,1 & 4,04 \\
\hline 2012 & 51423 & 685 & 52108 & 317274 & 2550 & 319824 & 6,17 & 3,72 \\
\hline 2013 & 42134 & 1293 & 43427 & 291978 & 4312 & 296290 & 6,93 & 3,33 \\
\hline 2014 & 33859 & 7048 & 40907 & 162555 & 7451 & 170006 & 4,8 & 1,57 \\
\hline 2015 & 31438 & 3028 & 33021 & 162218 & 5200 & 167418 & 5,16 & 1,72 \\
\hline 2016 & 27119 & 3158 & 30277 & 161598 & 5024 & 166622 & 5,9 & 1,61 \\
\hline
\end{tabular}

Source: Organization for tourism, culture and sport, Municipality of Sokobanja

Based on the data from Table 3, we can see the number of guests, the number of overnight stays and the length of stay that guests have achieved in the past twenty years on the territory of Sokobanja. It can be noted that the number of guests and realized overnight stays in Sokobanja, both domestic and foreign, was constantly increasing in the period from 1996-2008, when it increased by 50\%, but since the year of 2008. there has been a constant decline in the number of tourists. This can be associated with a reduction in capacity in hotel facilities. Hotel "Sunce" has stopped working in 2010, and it is in the process of ownership transformation. The reconstruction of the hotel is in constant progress, and this would mean increasing the capacity of the hotel accommodation. Also, the hotel "Zdravljak" does not work with full capacity, and its work is characterized by seasonality. Since the year of 2012, he only works during the summer months with reduced capacity. We can tell the same for the hotel "Turist", which is part of HTP Lepteria. The highest number of guests for the past twenty years was in 2001, when 68,120 guests were registered, but the largest number of overnight stays was recorded in 
the year before, in 2000, 572,111 nights. The length of guests' stay is in decline, and an increasing number of tourists are coming during the weekend. The big problem of monitoring the traffic of the guests is the negligence of the owners of private accommodation, which avoids the registration of guests, and the picture is not a real number of guests and overnight stays. It is considered that about $30 \%$ more of overnight stays are realized in the private sector, also it is related with the number of guests who visit Sokobanja. In recent years, the structure of guests has significantly changed. Even more young and family people visit Sokobanja. They are mostly weekend tourists and their stay is not longer than 3 days. The construction of Akvaparka "Podina" has a great contribution to the increase in the number of guests (Organization for Tourism, Culture and Sports of the Municipality of Sokobanja, 2017).

\section{SWOT ANALYSIS}

Based on the data from the previous text, a presentation of the strengths, weaknesses, chances and threats, or risks related to the further development of recreational tourism in the territory of Sokobanja municipality, has been made. The principle of action should be based on strengthening the benefits and utilizing the opportunities that exist, as well as on eliminating weaknesses and preventive action on identifying risks.

Table 4. SWOT Analysis

\begin{tabular}{|c|c|}
\hline Strength & Weaknesses \\
\hline $\begin{array}{l}\text { - Untouched nature, an ecologically clean area } \\
\text { - Natural resources: thermomineral sources, } \\
\text { direct mountain surroundings, unity of } \\
\text { landscapes } \\
\text { - Wealth of flora and fauna } \\
\text { - Famous hospitality towards guests }\end{array}$ & $\begin{array}{l}\text { - Undeveloped basic infrastructure } \\
\text { - Insufficient care for the protection of the } \\
\text { nature of all individuals involved in tourism } \\
\text { - Lack of a long-term tourism development plan } \\
\text { - The lack of cooperation and the creation of } \\
\text { partnerships with neighboring municipalities at } \\
\text { the regional level }\end{array}$ \\
\hline Opportunities & Threats \\
\hline $\begin{array}{l}\text { - The trend of complementary development of } \\
\text { spa and mountain tourism in Serbia and the } \\
\text { world } \\
\text { - Increasing demand for areas with preserved } \\
\text { natural resources } \\
\text { - Increasing awareness of the importance of } \\
\text { recreation and spa tourism in preserving the } \\
\text { overall health of people } \\
\text { - Creation of tourist clusters with the aim of } \\
\text { achieving better recognition of the tourist } \\
\text { product } \\
\text { - Exchange of experiences with already affirmed } \\
\text { European and world spa centers } \\
\text { - More and more popular use of electronic } \\
\text { media as a cheap way of promotion }\end{array}$ & $\begin{array}{l}\text { - Existence of other spa with a developed } \\
\text { tradition of recreational tourism in Serbia and } \\
\text { the environment } \\
\text { - Economic recession and poor purchasing } \\
\text { power of the domestic market } \\
\text { - Poor investment climate and long depreciation } \\
\text { periods are limiting factors for investors } \\
\text { - Unstable political situation in the world and } \\
\text { the region }\end{array}$ \\
\hline
\end{tabular}


Natural resources, and especially thermal mineral resources, can be used as the main strenght, which will be improved by adequate use and modernized by the tourist offer of Sokobanja. Using the thermal potential for filling the pool in spa centers, as well as heating the rooms, would improve the development of tourism. The main weakness is the lack of basic infra and suprastructure, as well as the lack of a long-term development plan. Complementary development of spa and mountain tourism, as well as cooperation with other economic entities in the surrounding area are the main chances for further development. Given that the funds allocated for the promotion of tourist destinations in Serbia are very limited, the popularity, the wide spatial coverage and the low price of advertising through the electronic media should be used. The economic recession and the lack of domestic and foreign investors, and fast development of spa centers in the region are the main threats to tourism in Sokobanja.

\section{CONCLUSION}

Sokobanja has exceptional natural potential for the development of recreational tourism. The natural environment that gives the opportunity to combine more activities for the purpose of active holidays needs to be valorized and directed towards demand. Tourist valorization is one of the most important steps in planning the future development of tourism in some area. It has great importance in preserving and protecting the environment (the immediate mountain environment, climate, thermo-mineral resources, as well as other hydrological facilities provide the opportunity to organize a large number of activities, which would differentiate Sokobanja offer from a simple spa and health resort. Modern medicine has proven that human recuperation is the fastest and has highest quality in nature. The classic type of vacation slowly loses its primacy, and the new form of active holiday takes it place in the world. The climate and untouched nature of this region sedativly affect the organism of human, the long and light walk through the forest complexes by marked paths, or trekking - mastering the mountain climb, picking medicinal herbs and collecting forest fruits, cycling, sailing or fishing, can definitely offer of Sokobanja on both domestic and international market. Further development Sokobanja should focus on environmental protection and preservation of the ecological potential of the space in the function of tourism, as well as the improvement of material development factors. Sokobanja should base its further development on merging into tourist clusters (eg, the tourist cluster of Eastern Serbia), in order to ensure adequate recognition and positioning on the domestic and foreign markets. Cooperation and exchange of experience with already well-established spa centers in Europe and the world would help to promote and create a unique tourist offer (Jovičić, 2002). The main disadvantage is the lack of quality accommodation capacities. Most of the hotels were built in the 70s and 80s and such a base does not match the quality of the offer that modern tourists expect. The seasonal character of these hotels has led to a decline in the number of tourists in recent years and a reduction in the number of overnight stays, which certainly affects the economy of this region. It is necessary to carry out ownership transformation of these facilities and modernize the offer that will correspond to 
the foreign market, as well as to build hotel facilities of high category $\left(4^{*}\right.$ and $\left.5^{\star}\right)$, which is also the strategic goal of the municipality of Sokobanja. It is also necessary to evaluate the natural potential that this municipality possesses with respect to the principles of sustainable development.

\section{REFERENCES}

Aleksić, S. (2005). Vodič kroz Sokobanju. Sokobanja

Bartoluci, M., Andrijašević, M. (2006). Aktivni odmor u unapređenju kvaliteta turističke ponude. Opatija: Hotelska kuća

Blagajac, M. (1992). Programirani aktivni odmor. Beograd

Jovanović, J., Radivojević, A. (2006). Turističko-geografski prikaz Sokobanje. Glasnik Srpskog geografskog društva, 86 (2), 287-299

Košić, K., Pivac, T., Romelić, J., Lazić, L., Stojanović, V. (2011). Characteristics of thermal-mineral waters in Backa region (Vojvodina) and their exploration in spa tourism. Renewable and Sustainable Energy reviews, 15, 801-807

Malinić, V., Stevanović, S. (2015). Turistička valorizacija antropogenih turističkih vrednosti gradske opštine Lazarevac. Zbornik radova DGTH, br.44, 62-85, Departman za geografiju, turizam i hotelijerstvo, Novi Sad

Marić, R., Radović, M. (1997). Sokobanja - koncept održivog razvoja turizma. Beograd: Ekonomski institut

Maćejka, M. (2003). Klima i njen zdravstveni značaj u banjama Srbije. Beograd: Srpsko geografsko društvo

Master plan turističke destinacije Sokobanja. 2007. Ministarstvo trgovine, turizma i usluga (Ministarstvo ekonomije i regionalnog razvoja - sektor turizma)

Jovičić, Ž. (2002). Turizam Srbije. Beograd: Turistička štampa

Organizacija za turizam, kulturu i sport opštine Sokobanja

Pavlović, M. (1995): Geogradske regije Srbije i Crne Gore. Beograd. Savremena administracija

Radivojević, A., Filipović, I., Dimitrijević, Lj., Nikolić, M. (2010). Geografske osnove razvoja turizma u sokobanjskoj kotlini. Glasnik srpskog geografskog društva, 90(3), $111-118$

Radivojević, A. (2008). Geografske promene u Sokobanjskoj kotlini i njihov uticaj na regionalni razvoj. Doktorska disertacija, Beograd: Geografski fakultet

Stanković, M., S. (2000). Turistička geografija. Beograd: Geografski fakultet

Stanković, S. Jovanović, V. (2006). Banje Srbije i njihov značaj za turizam, Zbornik radova: Planiranje, uredjenje i zaštita banjskih i klimatskih mesta Srbije, 13-25

Stanković, S., Pavlović, S. (2005): Banjski i planinski turizam Srbije, Zbornik radova $P M F, 53,75-90$

Čomić, Đ., Jović, G., Popović, I. (2008): Osnove turizma. Pale: Filozofski fakultet univerzitet u istočnom Sarajevu

http://www.sokobanja.travel/vodic/izletista/ripaljka 


\title{
МОГУЋНОСТИ ЗА РАЗВОЈ РЕКРЕАТИВНОГ ТУРИЗМА У СОКОБАҢИ
}

\author{
Милош Марјановић \\ Примљено: 03.06.2017. | Прихваћено: 21.07.2017.
}

\begin{abstract}
АПСТРАКТ: Савремени начин живота и рада има велики утицај на коришћење слободног времена и одмора. С обзиром на то да је савремени рад све мање динамичан и искључује физичку активност, у човеку се ствара потреба за одговарајућим активностима, којима ће у слободно време задовољити и надокнадити основне људске потребе, оличене у забави, кретању, рекреацији и игри, а све у циљу бољег и квалитетнијег начина живота. Активни одмор, као глобални тренд, крупним корацима заузима примат у коришћењу слободног времена код савременог човека. Србија је свакако изузетно интересантна као дестинација за развој овог вида туризма због своје природно-географске разноликости. Сокобања је једна од најзначајнијих и најпосећенијих бања у Србији и поседује изузетне потенцијале за упражњавање активног одмора. Климатске особености, непосредно планинско окружење, нетакнута природа, термоминерални извори и водени токови чине основу за развој савремених видова туризма - активни одмор. У овом раду биће анализирани потенцијали за развој рекреативног туризма на територији општине Сокобања, тренутно стање развоја, могућности за развој, материјална база и туристички промет, као и фактори који ограничавају динамичнији развој рекреативног туризма.
\end{abstract}

Кључне речи: Сокобања, рекреативни туризам, активни одмор

\section{УВОД}

Развој индустријализације у свету у 19. и 20. веку довео је до тога да је човек био све више отуђен од природе, све је мање имао времена за себе и све се брже трошио физички и психички. Таква отуђеност се негативно одражава на његов радни али и психофизички морал. Отуда се јављају разни протести радника за повећање њихових права. Јавља се потреба за рекреацијом. Велики број земаља уводи разне видове рекреације својих радника у циљу њиховог психо-фиичког опоравка и одмора. У бившим социјалистичким државама, у које спада и наша

\footnotetext{
I Цвијићева 9/19, 18000 Ниш, контакт: milos.marjanovic@mail.com
} 
земља, разне друштвене и синдикалне организације су били иницијатори масивнијег рекреативног кретања (С̌omić et al., 2008). У Србији се после Другог светског рата масовно активирају бањски и планински центри од којих су познатији Врњачка бања, Сокобања, Копаоник, Златибор и други и све већи број људи учествује у овом облику туристичких кретања.

Активни одмор је специфичан вид туризма који подразумева велики број активности усмерене на коришћење слободног времена и одмора, а које се непосредно везују за здрав живот, забаву и разоноду, у циљу обнављања и опоравка људске психо-физичке снаге. Модерни начин живота и рада, као и живот у урбаном окружењу, утиче на савремено друштво тако да све већи број људи прихвата активан начин одмарања (Blagajac, 1992). Човек примењује разне спортско-рекреативне активности чији садржаји представљају природне облике кретања, а у складу са својим здравственим стањем, способностима, потребама и интересима. С обзиром на то да се неке основне људске потребе као што су кретање, забава и игра могу задовољити спортом и рекреацијом, активни одмор представља нову тенденцију у развоју туризма, који се разликује од традиционалног садржаја одмора. Активни одмор укључује многобројне активности у атрактивном природном окружењу, које се разликују од свакодневних радних. Он у суштини представља начин одмарања уз помоћ разних активности, у циљу одржавања и побољшања психо-физичког стања организма у атрактивном природном окружењу (Bartoluci, Andrijašević, 2006).

Сокобања поседује природне потенцијале који су изузетни за активно упражњавање одмора. Велики број активности које доприносе успостављању или одржавању биолошке и психичке равнотеже могуће је упражњавати у атрактивном амбијенту сокобањске котлине, а неке од њих су планинарење, трчање, пешачење, пливање, вожња бицикла или ролера, рафтинг, једрење и сплаварење.

Сокобањска котлина се налази у централном делу источне Србије. Захвата површину од 525,5 km². У морфолошком погледу Сокобањска котлина представља део планинско-котлинско-долинске макрорегије, а мезорегије Источна Србија (Pavlović, 1995). Са свих страна је окружена планинама средње висине: Ртањ (1.567 m) на северу, на истоку су Слемен и Крстатац, на југоистоку је Девица, на југу Озрен, а на југозападу Буковик. Од Ниша је удаљена $60 \mathrm{~km}$, a $30 \mathrm{~km}$ од ауто-пута Е-75, главног правца кретања туриста у нашој земљи. Од Београда је удаљена $240 \mathrm{~km}$.

Могућности развоја рекреативног туризма у Сокобањи су базиране на богатству природних туристичких вредности као што су климатске карактеристике, вегетација, термоминерани извори и повољном туристичко-географском положају. Комплементарност развоја бањског са планинским туризмом је од фундаменталног значаја за даљи развој туризма у Сокобањи. Могућности развоја рекреативног туризма у Сокобањи су знатно веће од досадашњег стања, изграђености материјалне базе, садржаја и дужине туристичког боравка. Близина града Ниша, као главног емитивног подручја и близина аеродрома “Цар Константин” повећава туристичку вредност Сокобање. 


\section{ПРИРОДНИ РЕСУРСИ У ФУНКЦИЈИ РЕКРЕАТИВНОГ ТУРИЗМА У СОКОБАЮИ}

Природа сокобањског краја представља добру основу за развој туризма. Међутим, и поред тога добар део туристичких потенцијала није у довољној мери и на адекватан начин презентован туристичком тржишту. Због тога, али и због лоших економских услова (како на нивоу целе Србије, а посебно на простору источне Србије) туристички потенцијали Сокобањске котлине нису у довољној мери валоризовани што представља ограничавајући фактор даљег развоја. Боравак туриста на овом простору треба да се заснива на оптималној комбинацији атрактивних природних атрибута који ће директно омогућити активни одмор (Radivojević, 2010).

Сокобања поседује бројне и разноврсне природне туристичке вредности које представљају основу развоја туризма овог краја. Климатске особености, непосредно планинско окружење, термоминерални извори и водени токови пружају одличне услове за психо-физички одмор и опоравак човека.

Комбинација климатских фактора на територији Сокобање омогућава развој здравствено-лечилишног али и рекреативног туризма. Повољна климатска обележја која карактеришу сокобањску котлину, сврставају је у ред бањско-климатских места, односно Сокобања носи епитет ваздушне бање. Анализирајући стање појединих климатских елемената, клима Сокобање је дефинисана као клима конфора или зона угодног осећаја. То потврђује и податак да средња годишња темепратура ваздуха износи $10,29^{\circ} \mathrm{C}$. Најхладнији месец је јануар са просечном температуром од $-1,25^{\circ} \mathrm{C}$, а најтоплији је јул са $21,4^{\circ} \mathrm{C}$ (Maćejka, 2003). Просечан број дана у години са температуром ваздуха изнад $18^{\circ} \mathrm{C}$, који је погодан за туристичка кретања и сматра се туристичком сезоном, износи 92 дана. Просечна температура у зимском делу године износи $-0,6^{\circ} \mathrm{C}$, у пролеће $10,6^{\circ} \mathrm{C}$, лето $20,2^{\circ} \mathrm{C}$ и у јесесн $12,0^{\circ} \mathrm{C}$. Годишња количина падавина износи $599 \mathrm{~mm}$ и на основу тога Сокобања се сврстава у ред бања са минималном количином атмосферског талога што не утиче много на туристичка кретања (Maćejka, 2003). Релативна влажност ваздуха је највећа у зимским месецима са максимумом у децембру од $83 \%$, а најмања је у августу 68\%. Годишња вредност инсолације износи 1.861,5 h, односно просечно 5,09 h дневно (Radivojević, 2008). Комбинација климатских елемената овог простора седативно делује на организам човека. Клима Сокобање се може јавити као директна и као индиректна туристичка вредност. Уколико се јавља као елемент климатотерапије, односно у функцији рекреације, сматра се директном туристичком вредношћу. Као индиректна туристичка вредност, клима Сокобање се испољава кроз њено деловање на биљни и животињски свет, хидрогафске објекте и рељеф, потенцирајући њихову туристичку привлачност.

Могућности за развој различитих видова рекреативног туризма у уској су вези са морфолошким обележјима овог краја. У туристичком погледу, најинтересантније планине су Ртањ и Озрен. Ртањ, строги резерват природе, је највиша планина сокобањске котлине са врхом Шиљак (1.565 m). Ову планину карактерише изузетан пејзажно декоративни и угодни планински амбијент. Ртањ са својим атрактивним потенцијалом, отвара могућност развоја рекреативног туризма. До- 
бро обележене стазе које воде од подножја до врха, омогућавају вишечасовни успон у очуваном природном амбијенту. Постоје традиционалне акције као шту су Божићни или Ноћни успон, али постоје и многе друге акције које планинари и други љубитељи ове планине изводе, што самостално, што у групама. Интересантно је да је прилаз Ртњу могућ практично са свих страна, па се у зависности од тренутних интересовања и могућности појединаца, бира жељени пут. Бројни видиковци на Озрену и Девици чине и ове планине интересантним за туристичка кретања, и то пре свега за излете и шетње. Атрактивном потенцијалу Озрена доприноси и стимулативна суб-планинска клима, на основу које је, а према функционалној класификацији планина, Озрен и сврстан у групу планина опоравалишта (Stanković, 2000). Велики број уређених стаза води од подножја ових планина до самих врхова, а један од интересантнијих врхова за планинаре су Оштра чука, Чапљинац на Девици. Организовани успон на врх Оштра чука $(1.074 \mathrm{~m})$, Планинарски савез Србије је овај успон, који се одржава 24. септембра сваке године, уврстио у календар својих редовних активности.

Као изузетна погодност за развој рекреативног туризма на простору општине Сокобања имају разноврсне биогеографске туристичке вредности. Амбијенталну, рекреативну и пејзажну вредност овог простора повећава богата планинска вегетација која прекрива целу сокобањску котлину. Велике површине листопадних и четинарских шума, ливада и пашњака, уређених паркова и одморишта омогућавају дуге и лагане шетње обележеним стазама кроз нетакнуту природу, или вожњу бицикла по планинском терену. Уређени паркови у самој Сокобањи и непосредном окружењу дају велики допринос психо-физичком опоравку туриста. Неки од паркова су централни градски парк, парк "Бањица“, парк на Врелу (Борићи), парк „Чука 1“ и „Чука 2“. За туристе су јако привлачна и излетишта распоређена по ободу Сокобање до којих је могуће доћи пешака. То су Лептерија, Очно, Калиновица, извор реке Моравица. Посебну биогеографску вредност чини и самоникло лековито биље. Сокобањски крај је од давнина био познат по самониклом лековитом биљу: ртањски чај, кантарион, мајчина душица (Marić, Radović, 1997). Више од 200 различитих врста лековитог биља је пронађено на територији општине Сокобања. Брање лековитог биља и сакупљање шумских плодова су активности у којима туристи могу активно учествовати током свог боравка.

Термоминерални извори Сокобањске котлине чине њен примарни туристички ресурс, који у основи и одређује здравствено-лечилишну функцију бање. На основу извршене хидрорејонизације и извршених хемијских анализа сврставају се у радиоактивне акратотерме са карактером слабих земно алкалних вода. Све воде се одликују повећаном радиоактивношћу, што им даје посебан балнеолошки значај. На простору котлине термална вода се празни у шест локалности, извор Парк, термоминерални извор Преображење, извор Бањица I и Бањица II, Извор Моравица I извор Лептерија (Jovanović, Radivojević, 2006). Термоминерални потенцијал Сокобање није адекватно искоришћен. Развој бање треба да се фокусира на отварању wellnes \& spa центара, као један од водећих праваца развоја бања у свету. Термоминерални потенцијал требало би да се једним делом усмери у пуњење постојећих и изградњу нових базена са термоминералном водом, парних 
купатила, а други део би требало да служи за загревање истих, а активација постојеће инфраструктуре треба да буде приоритет у даљем развоју (Košić et al., 2011). Вештачко језеро Бован, и река Моравица су хидролошки објекти који омогућавају развој рекреативног туризма на овом простору. Због своје незагаћености реке сокобањске котлине (Моравица, Сеселачка река, Жлезовац) су погодне за различите видове рекреативног туризма, а посебно за развој спортског риболова. У том погледу посебно се истиче Моравица, где постоје и повољни услови за развој купалишног туризма (Aleksić, 2005). Вештачка акумулација Бован, настала преграђивањем реке Моравице ради снабдевања водом алексиначке општине, представља потенцијални туристички мотив. Уређене плаже, спортови на води, једриличарење, као и спортски риболов, само су неке од активности у којима туристи могу да уживају током свог боравка.

Поред рекреативних, неки облици рељефа имају и атрактивна својства везано за естетске и куриозитетне атрибуте као што су водопади, пећине и леденице. Водопад Рипаљка се налази на реци Градашница. Висок је $17 \mathrm{~m}$ и акумулативни је тип водопада. Први је споменик природе у Југославији заштићен законом из 1948. године (http://www.sokobanja.travel/vodic/izletista/ripaljka). Сесалачка пећина се налази недалеко од села Сесалац, петнаестак километара источно од Сокобање. Није туристички уређена, али је осветљена у дужини од 200 m, и може се лепо видети и сликати пећински накит који се налази у изобиљу. Леденица која се налази у подножју планине Ртањ, има дубину од $30 \mathrm{~m}$ и константну температуру од - $2^{\circ} \mathrm{C}$.

\section{СМЕШТАЈНИ КАПАЦИТЕТИ НАМЕЊЕНИ РЕКРЕАТИВНОМ ТУРИЗМУ У СОКОБАЬИ}

Средином 19. века почиње туристички развој Сокобање са изградњом првих смештајних објеката - комерцијалне виле, приватне собе, а самим тим и развој њене смештајне рецептиве. Године 1932. подигнута је прва вила, комерцијалниг типа, за смештај бањских гостију. Била је то вила „Македонија, годину дана касније подигнуте су још две виле на истом потезу, али нешто западније у односу на вилу Македонију. То су биле вила „Нада“ и „Бота“. Током наредне 1933. године, изграђене су још три виле: “Миланово“, вила “Србија“ и вила “Озрен“. Последње изграђене виле у периоду пре Другог светског рата биле су: вила “Мој одмор“, “Мишић“ и вила “Стојановић“ (Aleksić, 2005). Највећи напредак у развоју, Сокобања доживљава у периоду 1975-1987. године, када израста у један од највећих и најзначајних бањских и туристичких центара у тадашњој Југославији (Marić, Radović, 1997).

Данас Сокобања не располаже довољним капацитетима за смештај гостију у хотелским објектима. Сви хотели у Сокобањи су грађени средином 70-их година XX века. Дужи низ година се хотели налазе у процесу власничке трансформације, што у знатној мери отежава и одуговлачи прекопотребна инвестициона улагања за адаптацију и одржавање објеката. У Сокобањи нема хотела високе категорије, а за озбиљнији развој било ког вида туризма, основни туристички капа- 
цитети треба да задовоље потребе савременог туристе. Овакви капацитети су неопходни, поготово ако се има у виду интерес Сокобање да изађе на међународно тржиште и да постане један од водећих конгресних и здравствених центара Србије (Master plan turističke destinacije Sokobanja, 2007). Хотел „Сунце“ је у процесу власничке трансформације и тренутно је под реконструкцијом. Адаптација овог хотела знатно ће утицати на количину и квалитет хотелске понуде Сокобање. Последњих година је хотел „Здрављак“ отворен за посетиоце само у одређеним периодима године, и током значајнијих празника, тако да се знатно смањује понуда у хотелском смештају током године.

Табела 1. Број лежајева у хотелима и здравственим установама у Сокобањи

\begin{tabular}{|l|c|c|}
\hline Име објекта & Категорија & Број кревета \\
\hline хотел „Здрављак" & $3^{*}$ & 512 \\
\hline хотел Моравица & $3^{*}$ & 210 \\
\hline хотел Турист & $3^{*}$ & 105 \\
\hline хотел Сунце & $2^{*}$ & 184 \\
\hline Wellnеs\&sра центар Сокотерме & $3^{*}$ & 35 \\
\hline Укупно & & 1046 \\
\hline
\end{tabular}

Извор: Организација за туризам, културу и спорт општине Сокобања

Посебну категорију смештајних капацитета чине здравствени објекти, и то пре свега Специјална болница “Бањица” са 270 лежајева, Специјална болница “Сокобања” са 530 лежајева, као и специјална болница “Озрен” која нема комерцијални део за туристе.

Табела 2. Број и структура смештајних капацитета Сокобање у домаћој радиности

\begin{tabular}{|l|c|c|}
\hline Укупан број категорисаних соба у Сокобањи & \multicolumn{2}{|c|}{2.222 собе } \\
\hline \multirow{4}{*}{$\begin{array}{l}\text { Укупан број категорисаних лежајева у } \\
\text { домаћој радиности у Сокобањи }\end{array}$} & \multicolumn{2}{|c|}{4.837 лежајева } \\
\cline { 2 - 3 } & прва категорија & 1.517 лежајева \\
\cline { 2 - 3 } & друга категорија & 1.897 лежајева \\
\cline { 2 - 3 } & трећа категорија & 1.189 лежајева \\
\cline { 2 - 3 } & четврта категорија & 234 лежајева \\
\hline
\end{tabular}

Извор: Организација за туризам, културу и спорт општине Сокобања

Смештајни капацитети у приватном власништву су у иницијалној фази, без икакве системске контроле и планског развоја што утиче на њихову категоризацију (Radivojević et al.,2010). Верује се да у понуди има још око 10.000 кревета у смештају који није пријављен и није категорисан. Овај број је у константном порасту, јер се све већи број домаћинства укључује у понуду. На смањену попуњеност ових капацитета утиче ниво квалитета смештаја и услуга који се нуди, а који не задовољавају стандард савременог туристе. 


\section{АНАЛИЗА ТУРИСТИЧКОГ ПРОМЕТА}

Најбољи показатељ развоја туризма неког места јесте управо туристички промет. Организован развој туризма у Сокобањи датира још од 1837. године, када је у Сокобању дошао први гост, дакле пуних 180 година. Сокобања има туристичку и здравствену функцију, те се као таква сврстава међу центре са најдужом традицијом у развоју туризма. Сокобања се налази међу најпосећенијим бањама у Србији и заузима друго место са $14 \%$ од укупног туристичког промета, одмах иза Врњачке бање која реализује $26 \%$ од укупно реализованог бањског туристичког промета (Stanković, 2010).

Табела 3. Број гостију, број ноћења и дужина боравка у Сокобањи за период 1996-2016

\begin{tabular}{|c|c|c|c|c|c|c|c|c|}
\hline \multirow{2}{*}{ Година } & \multicolumn{3}{|c|}{ Број гостију } & \multicolumn{3}{c|}{ Број ноћења } & \multicolumn{2}{c|}{$\begin{array}{c}\text { Просечна дужина } \\
\text { боравка }\end{array}$} \\
\cline { 2 - 9 } & Домаћи & Страни & Укупно & Домаћи & Страни & Укупно & Домаћи & Страни \\
\hline 1996 & 40836 & 237 & 41073 & 238404 & 365 & 238769 & 5,8 & 1,2 \\
\hline 1997 & 46872 & 452 & 47324 & 254751 & 1211 & 255962 & 5,4 & 1,8 \\
\hline 1998 & 64955 & 586 & 65541 & 528099 & 1614 & 529713 & 8,1 & 2,3 \\
\hline 1999 & 51051 & 482 & 51533 & 374124 & 1522 & 375646 & 7,3 & 1,3 \\
\hline 2000 & 65434 & 840 & 66274 & 568575 & 3536 & 572111 & 8,7 & 4,2 \\
\hline 2001 & 67226 & 894 & 68120 & 439529 & 3650 & 443579 & 6,5 & 4,4 \\
\hline 2002 & 66141 & 1036 & 67177 & 418422 & 2213 & 420635 & 6,3 & 2,1 \\
\hline 2003 & 60297 & 1463 & 61760 & 396848 & 5852 & 402700 & 6,6 & 4 \\
\hline 2004 & 63049 & 1633 & 64682 & 408538 & 6042 & 414580 & 6,5 & 3,7 \\
\hline 2005 & - & - & 65870 & - & - & 413403 & & 6,27 \\
\hline 2006 & - & - & 67690 & - & - & 412393 & & 6,09 \\
\hline 2007 & 60235 & 1046 & 61281 & 365480 & 5269 & 370749 & 6,07 & 5,03 \\
\hline 2008 & 63128 & 1152 & 64280 & 376850 & 4816 & 381666 & 5,97 & 4,18 \\
\hline 2009 & 55686 & 1263 & 56949 & 330901 & 4959 & 335860 & 5,94 & 3,93 \\
\hline 2010 & 49056 & 1027 & 50083 & 299325 & 3152 & 302477 & 6,1 & 3,07 \\
\hline 2011 & 54984 & 959 & 55943 & 335458 & 3882 & 339340 & 6,1 & 4,04 \\
\hline 2012 & 51423 & 685 & 52108 & 317274 & 2550 & 319824 & 6,17 & 3,72 \\
\hline 2013 & 42134 & 1293 & 43427 & 291978 & 4312 & 296290 & 6,93 & 3,33 \\
\hline 2014 & 33859 & 7048 & 40907 & 162555 & 7451 & 170006 & 4,8 & 1,57 \\
\hline 2015 & 31438 & 3028 & 33021 & 162218 & 5200 & 167418 & 5,16 & 1,72 \\
\hline 2016 & 27119 & 3158 & 30277 & 161598 & 5024 & 166622 & 5,9 & 1,61 \\
\hline
\end{tabular}

Извор: Организација за туризам, културу и спорт општине Сокобања

На основу података из табеле 3, може се пратити број гостију, број остварених ноћења и дужина боравка који су гости остварили у протеклих двадесет година на територији Сокобање. Може се приметити да је број гостију и остварених ноћења 
у Сокобањи, како домаћих тако и страних био у константом порасту у периоду од 1996-2008, када се повећао 50\%, међутим од 2008. године се бележи константни пад броја туриста. Ово се може повезати са смањењем капацитета у хотелским објектима. Наиме, хотел “Сунце” је престао са радом 2010. године, и у процесу је власничке трансформације. Увелико се врши реконструкција хотела и то би значило повећање капацитета у хотелском смештају. Такође, хотел “Здрављак” не ради пуним капацитетом, и његов рад карактерише сезоничност. Од 2012. године он ради само током летњих месеци и то смањеним капацитетом. Исто важи и за хотел “Турист” који је у склопу ХТП Лептерија. Највећи број гостију за протеклих двадесет година је било у 2001. години, када је забележено 68.120 гостију, али је највећи број ноћења остварен годину дана раније, 2000. године, 572.111 ноћења. Дужина боравка гостију је у опадању, и све већи број туриста долази током викенда. Велики проблем праћења промета гостију прави немарност власника приватног смештаја, који избегавају пријављивање гостију, те слика није реално стање броја гостију и остварених ноћења. Сматра се да се у приватном сектору оствари још око $30 \%$ ноћења током године и исто толико гостију који посете Сокобању. Последњих година знатно се променила структура гостију. Све више младих и породичних људи посећује Сокобању. Углавном су то викенд туристи и њихов боравак није дужи од 3 дана. Велики допринос томе има изградња Аквапарка "Подина" (Организација за туризам, културу и спорт општине Сокобања, 2017).

\section{SWОТ АНАЛИЗА}

На основу података из претходног текста, урађен је приказ снага, слабости, шанси и претњи, односно ризика који су везани за даљи развој рекреативног туризма на територији општине Сокобања. Принцип деловања треба да се заснива на јачању предности и искоришћавању шанси које постоје, као и на елиминацији слабости и превентивног деловања на идентификовању ризика.

Као главна снага могу се узети природни ресурси, а поготово термо-минерални извори, чијом би се адекватном применом унапредила и осавременила туристичка понуда Сокобање. Искоришћавање термалног потенцијала за пуњење базена у спа центрима, као и загревање просторија у много би олакшао и унапредио развој туризма. Главна слабост је недостатак базичне инфра и супрастуктуре, као и непостојање дугорочног плана развоја. Комплементарни развој бањског и планинског туризма, као и сарадња са осталим привредним субјектима у окружењу су главне шансе за даљи развој. С обзиром на то да су средства која се издвајају за промоцију туристичких дестинација у Србији врло ограничена, треба искористити популарност, широк просторни обухват и ниску цену оглашавања путем електронских медија. Економска рецесија и недостатак домаћих и иностраних улагача, као и све бржи развој бањских центара у окружењу су главне претње по туризам Сокобање. 
Табела 4. SWOT Анализа

\begin{tabular}{|c|c|}
\hline Снаге & Слабости \\
\hline $\begin{array}{l}\text { - Нетакнута природа, еколошки чисто под- } \\
\text { ручје } \\
\text { - Природни ресурси: термоминерални изво- } \\
\text { ри, непосредно планинско окружење, је- } \\
\text { динство пејзажа } \\
\text { - Богатство флоре и фауне } \\
\text { - Познато гостопримство према гостима }\end{array}$ & $\begin{array}{l}\text { - Неразвијена базична инфраструктура } \\
\text { - Недовољна брига о заштити природе свих } \\
\text { појединаца укључених у туризам } \\
\text { - Непостојање дугорочног плана развоја ту- } \\
\text { ризма } \\
\text { - Изостанак сарадње и стварање партнер- } \\
\text { ства са суседним општинама на нивоу ре- } \\
\text { гије }\end{array}$ \\
\hline Шансе & Претње \\
\hline $\begin{array}{l}\text { - Тренд комплементарног развоја бањског и } \\
\text { планинског туризма у Србији и у свету } \\
\text { - Све већа потражња за пределима са очува- } \\
\text { ним природним ресурсима } \\
\text { - Повећање свести о значају рекреације } \\
\text { и бањског туризма у очувању општег } \\
\text { здравља људи } \\
\text { - Стварање туристичких кластера са циљем } \\
\text { да се постигне боља препознатљивост ту- } \\
\text { ристичког производа } \\
\text { - Размена искуства са већ афирмисаним ев- } \\
\text { ропским и светским бањским центрима } \\
\text { Све популарнија употреба електронских } \\
\text { медија као јефтиног начина промоције }\end{array}$ & $\begin{array}{l}\text { - Постојање других бања са развијеном тра- } \\
\text { дицијом рекреативног туризма у Србији и } \\
\text { окружењу } \\
\text { - Економска рецесија и слаба куповна моћ } \\
\text { домаћег тржишта } \\
\text { - Лоша инвестициона клима и дуг пери- } \\
\text { од амортизације представљају огранича- } \\
\text { вајуће факторе за инвеститоре } \\
\text { - Нестабилна политичка ситуација у свету и } \\
\text { региону }\end{array}$ \\
\hline
\end{tabular}

\section{ЗАКљУЧАК}

Сокобања има изузетан природни потенцијал за развој рекреативног туризма. Природно окружење које даје могућност за комбиновање више активности у циљу активног одмора, је потребно валоризовати и усмерити ка тражњи. Туристичка валоризација је једна од најзначајнијих корака у планирању будућег развоја туризма неког простора. Има велики значај у очувању и заштити животне средине (непосредно планинско окружење, клима, термоминерални извори, као и остали хидролошки објекти пружају могућност за организовање великог броја активности, који би диференцирали понуду Сокобање од чисто бањско-лечилишног места. Савремена медицина је доказала да се човек најбрже и најквалитетније одмори управо кроз активности у природи. Класичан вид одмора полако губи свој примат, а нови вид активног одмора узима маха свуда у свету. Клима и нетакнута природа овог краја седативно делује на организам човека, дуге и лагане шетње кроз шумске комплексе обележеним стазама или треккинг - савладавање планинског успона, брање лековитог биља и сакупљање шумског воћа, вожња бицикла, једриличарство или риболов, свакако да може да издвоји понуду Сокобање на домаћем па и интернационалном тржишту. Даљи развој Сокобање треба да се 
усмери ка заштити животне средине и очувању еколошког потенцијала простора у функцији туризма, као и побољшање материјалних фактора развоја. Сокобања би свој даљи развој требало да базира на удруживању у туристичке кластере (нпр. туристички кластер Источне Србије), како би обезбедила адекватну препознатљивост и позиционираност на домаћем и на страном тржишту. Сарадња и размена искуства са већ афирмисаним бањским центрима Европе па и света би доста помогло унапређењу и креирању јединствене туристичке понуде (Jovičić, 2002). Главни недостатак јесте мањак квалитетних смештајних капацитета. Већина хотела је грађена 70-их и 80-их година и таква база не одговара квалитету понуде који савремени туриста очекује. Сезонски карактер рада ових хотела довео је до пада броја туриста последњих година и смањење броја остварених ноћења, што свакако утиче и на економију овог краја. Потребно је извршити власничку трансформацију ових објеката и осавременити понуду која ће одговарати иностраном тржишту, као и изградити хотелске објекте високе категорије $\left(4^{\star}\right.$ и $\left.5^{\star}\right)$ што је и стратешки циљ општине Сокобања. Такође је потребно валоризовати природни потенцијал који ова општина поседује уз поштовање принципа одрживог развоја.

\section{ЛИТЕРАТУРА}

Aleksić, S. (2005). Vodič kroz Sokobanju. Sokobanja

Bartoluci, M., Andrijašević, M. (2006). Aktivni odmor u unapređenju kvaliteta turističke ponude. Opatija: Hotelska kuća

Blagajac, M. (1992). Programirani aktivni odmor. Beograd

Jovanović, J., Radivojević, A. (2006). Turističko-geografski prikaz Sokobanje. Glasnik Srpskog geografskog društva, 86 (2), 287-299

Košić, K., Pivac, T., Romelić, J., Lazić, L., Stojanović, V. (2011). Characteristics of thermal-mineral waters in Backa region (Vojvodina) and their exploration in spa tourism. Renewable and Sustainable Energy reviews, 15, 801-807

Malinić, V., Stevanović, S. (2015). Turistička valorizacija antropogenih turističkih vrednosti gradske opštine Lazarevac. Zbornik radova DGTH, br.44, 62-85, Departman za geografiju, turizam i hotelijerstvo, Novi Sad

Marić, R., Radović, M. (1997). Sokobanja - koncept održivog razvoja turizma. Beograd: Ekonomski institut

Maćejka, M. (2003). Klima i njen zdravstveni značaj u banjama Srbije. Beograd: Srpsko geografsko društvo

Master plan turističke destinacije Sokobanja. 2007. Ministarstvo trgovine, turizma i usluga (Ministarstvo ekonomije i regionalnog razvoja - sektor turizma)

Jovičić, Ž. (2002). Turizam Srbije. Beograd: Turistička štampa

Organizacija za turizam, kulturu i sport opštine Sokobanja

Pavlović, M. (1995): Geogradske regije Srbije i Crne Gore. Beograd. Savremena administracija 
Radivojević, A., Filipović, I., Dimitrijević, Lj., Nikolić, M. (2010). Geografske osnove razvoja turizma u sokobanjskoj kotlini. Glasnik srpskog geografskog društva, 90(3), $111-118$

Radivojević, A. (2008). Geografske promene u Sokobanjskoj kotlini i njihov uticaj na regionalni razvoj. Doktorska disertacija, Beograd: Geografski fakultet

Stanković, M., S. (2000). Turistička geografija. Beograd: Geografski fakultet

Stanković, S. Jovanović, V. (2006). Banje Srbije i njihov značaj za turizam, Zbornik radova: Planiranje, uredjenje i zaštita banjskih $i$ klimatskih mesta Srbije, 13-25

Stanković, S., Pavlović, S. (2005): Banjski i planinski turizam Srbije, Zbornik radova $P M F, 53,75-90$

Čomić, Đ., Jović, G., Popović, I. (2008): Osnove turizma. Pale: Filozofski fakultet univerzitet $\mathrm{u}$ istočnom Sarajevu

http://www.sokobanja.travel/vodic/izletista/ripaljka 